\title{
XXI. On the colour of steam under certain circumstances
}

\section{Professor Forbes}

To cite this article: Professor Forbes (1839) XXI. On the colour of steam under certain circumstances, Philosophical Magazine Series 3, 14:86, 121-126, DOI: 10.1080/14786443908649681

To link to this article: http://dx.doi.org/10.1080/14786443908649681

册 Published online: 20 Aug 2009.

Submit your article to this journal $₫$

Џll Article views: 5

Q View related articles $₫$ 


\begin{tabular}{|c|c|c|c|}
\hline & & $\begin{array}{l}\text { Deaths in } \\
1000 .\end{array}$ & $\begin{array}{l}\text { Deaths by } \\
\text { Fever. }\end{array}$ \\
\hline 4. & Spanish 'Town. & $162-4$ & $141-1$ \\
\hline 5. & Tobago........ & $152-8$ & $104-1$ \\
\hline 6. & Port Antonio ..... & $149-3$ & $126--0$ \\
\hline 7. & Up Park Camp & $140-6$ & $120-8$ \\
\hline 8. & Dominica........... & $137-4$ & $49-3$ \\
\hline 9. & St. Lucia....................... & $122-8$ & $63-1$ \\
\hline 10. & Port Royal ..... & $113-1$ & $93-9$ \\
\hline 11. & Trinidad .......... & $106-3$ & $61-6$ \\
\hline 12. & Falmouth........... & $102-6$ & $80-0$ \\
\hline 13. & Hill .. & $90-2$ & $70-5$ \\
\hline 14. & British Guiana & $84-0$ & $59-2$ \\
\hline 15. & 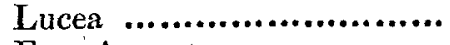 & $84-9$ & $63-2$ \\
\hline 16. & Fort Augusta ........... & $73-5$ & $55-5$ \\
\hline 17. & St. Kits, Nevis and Tortola & $71-0$ & $42-1$ \\
\hline 18. & Grenada ............. & $61-8$ & $26-3$ \\
\hline 19. & Barbadoes ... & $58-5$ & $11-8$ \\
\hline 20. & St. Vincents............... & $54-9$ & $11-2$ \\
\hline 21. & and Montserrat....... & $40-6$ & $14-9$ \\
\hline 22. & Maroon Town ............... & $32-7$ & $15-3$ \\
\hline
\end{tabular}

The most sickly as well as the most fatal period of the year extends from August to December, and during this time the winds are generally from the south and west. The least unhealthy months are March, April, and May, when the tradewind blows from the east. The annual mortality of the troops in England has for a long series of years been only fifteen to the thousand.

XXI. On the Colour of Steam under certain circumstances. By Professor Fonbes*.

I the end of May or beginning of June last, I happened to stand near a locomotive engine on the Greenwich railway, which was discharging a vast quantity of high pressure steam by its safety valve. I chanced to look at the sun through the ascending column of vapour, and was struck by seeing it of a very deep orange red colour, exactly similar to dense smoke, or to the colour imparted to the sun when viewed through a common smoked glass.

I did not pay much attention to the fact at the moment, nor did I attempt to vary the experiment; but reflecting on it af-

* Communicated by the Author. 
terwards it seemed to me not only as in itself very singular, but as still more extraordinary that I should never have heard of a property of steam which must have been witnessed by thousands of persons. Some months after (in the end of October), being on the Newcastle and Carlisle railway, I resolved to verify the fact, which I had no difficulty in doing, and I further discovered a very important modification of it. For some feet or yards from the safety valve at which the steam blows, its colour for transmitted light is the deep orange red I have described ${ }^{*}$. At a greater distance, however, the steam being more fully condensed, the effect entirely ceases : even at moderate thicknesses the steam cloud is absolutely opake to the direct solar rays, the shadow it throws being as black as that of a dense body ; and when the thickness is very small it is translucent, but absolutely colourless, just like thin clouds passing over the sun, which have indeed a perfect analogy of structure. When the steam is in this state no indication of colour is perceptible in passing from the thickness corresponding to translucency to that which is absolutely opake.

Having made these observations, which were all that the circumstances enabled me to accomplish, I was very anxious to verify them with steam of various pressures, and to determine the following amongst other points: (1) whether steam in its purely gaseous form is really, as commonly supposed, colourless; (2) whether the colour depends on a stage in the process of condensation, and on that alone; (3) what effect the tension of the steam has upon the phænomena.

But there was another inquiry which interested me much more than all these, which was to examine how the spectrum was affected by the absorbent action of the steam, which left the red and orange rays predominant. Judging from the phrenomena of absorption of light by gaseous bodies, and especially the singular action of nitrous acid gas in dividing the spectrum into a vast number of bands, discovered by Sir D. Brewster, I thought it by no means improbable that steam acting in a similar manner might exercise its specific action upon the prismatic colours at many points. Should this conjecture be confirmed, I also foresaw an application to the phænomena of the atmosphere and the production of the atmospheric lines of the solar spectrum also remarked by Sir D. Brewster.

After various ineffectual attempts to obtain the requisite fa-

- The same may be observed daring the ordinaryprogress of the engine in the steam thrown into the chimney, but the presence of smoke renders the experiment less satisfactory. 
cilities, Mr. Edington of the Phœnix iron-works at Glasgow most kindly put at my disposition an excellent high-pressure boiler, and further afforded me every facility for prosecuting my experiments on the optical properties of steam. I first examined the simple phænomena of colour as seen by the naked eye. A lantern * was held behind a jet of steam issuing from a stopcock in the top of the boiler, having a bore of $\frac{1}{4}$ inch. When the safety valve (which acted with great promptness) was loaded with 50 pounds on the inch, the steam issued nearly invisible, and at the small thickness of the jet in that part perfectly colourless. As the light was raised the orange colour appeared at the height of a few inches above the cock, and rapidly deepened up to a height of about 20 inches, after which it appeared that the rapid condensation of the steam only rendered it more opake without deepening its hue. At that point therefore I resolved to transmit the light and to analyse by a prism. A theodolite and good prism in front of the telescope were placed at the distance of about 25 feet from the boiler; beyond the steam-cock a lantern with a lens for parallel rays was adjusted, and between the steam-cock and the prism a slit of variable width. The light reaching the prism through the slit must first pass through the column of steam at a height of about 20 inches from the orifice. To test the adjustment of the apparatus, and also for the purpose of contrast, I had provided a bottle, about 5 inches in diameter, full of remarkably dense nitrous acid gas, which $\mathrm{Mr}$. Kemp was so good as to prepare for me. When this was placed where the steam was to issue, the appearance of the nitrous acid spectrum was magnificently displayed. I then removed the bottle and opened the steam-cock gradually (the pressure on the safety-valve being 55 pounds above the atmosphere, or the tension of the steam $4 . \frac{2}{3}$ atmospheres), the violet end of the spectrum was almost instantly absorbed, then the whole blue and part of the green, just as in the nitrous acid spectrum, but no lines roere visible in the remaining part. When the cock was fully opened the spectrum exhibited a singular appearance; the bright red was the only part which seemed natural. The extreme red was slightly invaded by the opacity of the steam. Most of the orange, the yellow, and as much of the green as was not absorbed had a dirty disagreeable hue, which I de-, scribed in a memorandum at the time as "dingy, alternating between yellow and purple, with shades of green; when the steam had its highest pressure there was a decidedly purple tinge." The appearance to the naked eye of the slit was now identically the colour of the nitrous acid

* The experiments were performed at night. 
gas, through which I from time to time viewed a distant gas flame, and compared it with the colour of the slit. The experiment was performed under 50 and 55 pounds many times over. The light examined was then caused to pass through the steam only 10 inches from the orifice of the stop-cock, under the idea that though the colour there was fainter, possibly there might be a tendency to develope lines in the spectrum. But the experiment being made under the same pressure as before, the effect was similar, only much less intense : the slit had now but a faint tawny colour, and prismatic analysis showed the violet alone absorbed.

Steam blowing off at 25 pounds, the lantern and slit 20 inches above the orifice as at first. To the eye the light appeared as red as under 55 pounds. Mr. Edington observed that the colour was deeper than that of the nitrous acid gas bottle. Neither he nor his assistant ever observed the colour of steam before. Prismatic phænomena as before; only the obscuration not quite so great.

Steam blowing off at 15 pounds. "Evidently redder than the gas bottle: same phænomena of spectrum, but green remains pure throughout, and verges on (bounds immediately with) orange. During the absorption of violet before vanishing (the steam-cock being gradually opened) it assumes a dirty white colour, verging on yellow and purple." A common lamp was viewed through different parts of the column of steam of this pressure, from the orifice up to a height of 5 or 6 feet, and wherever it was not entirely obscured, it appeared of different shades of smoke colour up to an intense tawny orange.

With 7 pounds on the inch. Still visibly red to the eye; prismatic phænomena similar but slighter.

With 4 pounds, no longer visibly red to the eye when arranged as above; and seen with the prism the violet appears but little affected. When let off in large quantity from the safety-valve, and a lamp viewed through it, there is a faint redness close to the orifice, but every where above, the transition is from colourless translucency to complete opacity. At about 2 and 1 pound no colour can be detected.

From these experiments I deduce the following conclusions :

(1.) Steam in its purely gaseous form is, as commonly supposed, colourless, at least at small thicknesses.

(2.) The orange red colour of steam by transmitted light appears to be due to a particular stage of the condensing process. Before condensation, steam is colourless and transparent; it is next transparent and smoke-coloured; finally it 
becomes colourless at small thicknesses, and absolutely opake at greater.

(3.) The state of tension of the steam seems only to affect the phænomena so far as it renders the critical colorific stage of condensation more or less completely observable.

(4.) The absorptive action of steam on the spectrum is not exerted in the same way as that of other gaseous coloured bodies, such as nitrous ucid gas, and iodine vapour. It cuts off; however, totally the same part of the spectrum as nitrous acid does. Its phænomena perhaps have a greater analogy to those of opalescence than any other.

The effect of mere change of mechanical structure in altering the optical properties of bodies is a phænomenon likely to give important information, both as to the constitution of matter and the constitution of light; and the present observations may perhaps be one day viewed as a contribution towards a mechanical theory of vapour, including that most singular stage which intervenes between the gaseous and completely liquid form, and which is probably connected with the mechanical suspension of clouds. It is at all events very important to know that a portion of watery vapour confined in a close vessel, and subjected to change of temperature alone, without chemical change, is capable of undergoing the alterations of colour and transparency which have been adverted to. The singular fact noticed by Sir D. Brewster in the case of nitrous acid gas, the colour of which deepens to an intense orange red by the simple application of heat, seems to be a fact of this kind.

I cannot doubt that the colour of watery vapour under certain circumstances is the principal or only cause of the red colour observed in clouds. The very fact that that colour chiefly appears in the presence of clouds, is a sufficient refutation of the only explanation of the phrnomena of sunset and sunrise having the least plausibility, given by optical writers. If the red light of the horizontal sky were simply complementary to the blue of a pure atmosphere, the sun ought to set red in the clearest weather, and then most of all; but experience shows that a lurid sunrise or sunset is always accompanied by clouds, or diffused vapours, and in a great majority of cases occurs when the changing state of previously transparent and colourless vapour may be inferred from the succeeding rain. In like manner terrestrial lights seen at a distance grow red and dim when the atmosphere is filled with vapour soon to be precipitated. Analogy applied to the preceding observations would certainly conduct to a solution of such appearances; for I have remarked that the existence of vapour of 
high tension is by no means essential to the production of colour, though of course a proportionally greater thickness of the medium must be employed to produce a similar effect when the elasticity is small.

Glasgow, Dec. 29, 1838.

XXII. Remarlss on a paper in the Philosophical Magazine for December 1838, on a certain demonstration of Euclid. By A Correspondent.

To the Editors of the Philosophical Magazine and Journal. Gentuemen,

T $N$ this month's number of the Philosophical Magazine (Dec. 1838. vol. xiii. p. 434) one of your correspondents has given a method of dispensing with the 12th axiom of the 1st book of Euclid's Elements, apparently not being aware that Professor Peacock has given the same in his treatise on algebra. It would, indeed, be immediately suggested by a perusal of the demonstration of the 12th axiom, and the remarks upon it by Ptolemy, quoted by Proclus in his commentary on Euclid's Elements.

It appears to me to be open to the objection which Proclus makes to the emendations of Eneas Hierapolites, and others on the Elements, "for the geometrician appears to have chosen such hypotheses as either abound in affirmation or are more simple." Setting aside other more weighty objections, Professor Peacock's proposed amendment, although it removes one difficulty, is certainly not sufficiently simple to be placed among the definitions of the 1 st book. When I say not sufficiently simple, I mean that it does not immediately impress upon one's mind the common idea of the subject defined, an object to which Euclid has always been careful to adhere.

Your obedient Servant,

Jesus College, Cambridge, Dec. 1st, 1238.

J. O. H.

XXIII. Notice of the Electrical Excitation of a Leatiher Strap connecting the Drums of a Worsted Mill; in a letter to Dr. Faraday from the Rev. T. DruRY*.

My Dear Sir,

PERMIT me to describe an extraordinary electrifying machine which I yesterday witnessed, and which I think will be new even to you.

* Communicated by Dr. Faraday. 